\title{
A sustainability analysis of the exploitation of the baru almond (Dipteryx alata Vogel) in the Brazilian Savanna
}

\author{
Uma análise sobre a sustentabilidade da exploração da \\ amêndoa do baru (Dipteryx alata Vogel) no Cerrado \\ brasileiro
}

Rogério Marcos Magalhães

Doutor em Desenvolvimento Sustentável, analista ambiental, Serviço Florestal Brasileiro, Brasília, DF, Brasil. E-mail: rogerio.magalhaes58@gmail.com

doi:10.18472/SustDeb.v10n2.2019.25666

Received: 03/07/2019

Accepted: 13/08/2019

ARTICLE - VARIA

\begin{abstract}
This article seeks to discuss the results of a survey that sought to identify, by means of indicators and social-economic information, if the exploitation of the baru nut (Dipteryx alata Vogel) - a Brazilian species from the savanna - represents a sustainable alternative to generate income for family farmers in Goias and the Federal District. The results showed that, under the current circumstances, the baru extrativism done by family farmers isn't a sustainable income generation activity. This result considers the premise that for an activity to be sustainable, it needs to show equilibrium among the various factors of sustainability. The obstacles that the family farmers of the baru nut production chain face may be prejudicial to the proper exploitation of the nut, which could compromise the sustainability of the activity as a whole.
\end{abstract}

Keywords: Baru; Production Chain; Sustainability; Forest Extrativism.

\section{RESUMO}

Esse artigo visa discutir os resultados obtidos com a pesquisa que buscou identificar, por meio de indicadores e de informações socioeconômicas, se a atividade de exploração da amêndoa do baru (Dipteryx alata Vogel) - uma espécie arbórea do Cerrado brasileiro - realizada por agricultores familiares estabelecidos em municípios goianos e no Distrito Federal, pode ser caracterizada como uma alternativa sustentável de geração de renda. Os resultados demonstraram que nas condições encontradas, a exploração do baru não se configura como uma atividade sustentável de geração de renda, uma vez que atende parcialmente ao pressuposto segundo o qual a atividade para ser considerada sustentável deve possuir um equilíbrio entre as várias dimensões da sustentabilidade. Os obstáculos que os agricultores familiares da cadeia produtiva do baru enfrentam podem constituir em poderoso entrave à adequada exploração da castanha, contribuindo também para o comprometimento da sustentabilidade da atividade.

Palavras-chave: Baru; Cadeia Produtiva; Sustentabilidade; Extrativismo Vegetal. 


\section{INTRODUCTION}

The nut of the fruit of the baru tree (Dipteryx alata Vogel) is part of the food intake of the indigenous people and family farmers who inhabit the savanna, which covers the central region of Brazil (Biome Savanna). The species belongs to the family Leguminosae (Fabaceae) and individuals reach an average height of $15 \mathrm{~m}$ and can reach $25 \mathrm{~m}$ in fertile soils. Fruiting in the state of Goias occurs between July and October, varying from place to place (SANO et al., 2004). The fruit falls to the ground when it matures and it is consumed by cattle, rodents and ants, while also being collected, mainly, by the inhabitants of the rural zone. Its almond is usually extracted by rudimentary tools and when it is meant for human consumption it is toasted in order to reduce trypsin inhibitor (TAGASHI; SGARBIERI, 2005) that indirectly affects the absorption of essential amino acids. Currently, it is highly sought after for preparation of food products, such as bread, ice cream, liqueur, traditional dishes, among others, and it has reached a good market price.

The sustainable development approach is based on the harmonization of social, environmental and economic objectives (SACHS, 2000). This assumption presupposes that the exploitation of biodiversity (biomass) must seek balance among the dimensions of sustainability. Having said that, the exploration of the baru almond by family farmers in the Savanna Biome should reconcile the ecological, social, economic, political and health dimensions in order to be considered sustainable. Even though this activity in itself provokes very little environmental impact, the balance among these dimensions is measured by the level of well-being of the human communities involved in the activity.

The correct measurement of sustainable development has raised many doubts (HARDI; ZDAN, 1997). Being a parameter or a value derived from parameters, which provides information about a phenomenon (OECD, 1993), it can be a very useful tool to formulate public policies. For Bellen (2005), the objective of the indicators "is to aggregate and quantify information, so that its significance becomes more apparent" (p. 42). Bellen (2005) compared three tools for establishing sustainability indicators - Ecological Footprint, Sustainability Barometer and Sustainability Panel - concluding that indicator systems are an important legitimizing element in determining the public and social agenda for development.

Extractivism in Brazil has been the object of theoretical studies in an attempt to explain and develop it, as well as empirical research to validate it. Drummond (1996) categorizes as low-tech extractivism those practices that do not require complex technological or mechanical mediations between humans and natural resources. The extraction activity is part of the strategy of survival of human groups that develop agriculture, livestock, commerce, crafts, service and industry. For Homma (1993), the extractivism can be understood as a process that is limited to the collection of existing products in nature, with low productivity or declining productivity tending to go extinct with the passage of time.

According to Rego (1996), the extractivism practiced today can be considered as a model of sustainable development, based on the culture of extractivist populations and family productive systems that harmonize economic, social and environmental benefits. Production in this system is based on family or community work. It is subject to natural cycles, depending on the immediate use of resources and has as rationale social and cultural reproduction, instead of profit.

The extractive activity of forest products faces difficulties that constitute a strong obstacle to its realization, compromising its sustainability. Family farmers who practice exploration of non-timber forest products (NTFPs) as a means of obtaining foreign currencies face obstacles which tend to turn their production inviable. These barriers can occur in a variety of ways: inadequate regulatory frameworks (sanitary, environmental and fiscal); lack of capacity of the farmer for the various stages of the productive process; inadequate infrastructure for resource exploitation; low inventory capacity; difficulties in accessing credit; low efficiency and absence of extension services and producer orientation; incipience of the market logistics chain (distribution and trade) of these products, or even the lack of resources that could help entrepreneurs achieve good results: good knowledge of the market in which they operate; good sales strategy; persistence, perseverance and creativity; good management and search of equity for their businesses (SEBRAE, 2007). 
Efforts to remove these obstacles have mobilized some sectors of society because the benefits that a sustainable use of biodiversity can bring to the country, especially through the possibility of articulated sustainability actions that generate environmental gains, such as the maintenance of ecosystem functions (water, biodiversity and climate) in vast areas of the national territory, promote the generation of complementary income and food security (SAWYER, 2009).

This study was carried out in 2011 and its main objective was to identify, through indicators and socioeconomic information, whether the activity of baru almond in two municipalities in Goias can be characterized as a sustainable income generation alternative for family farmers. The productive chain of the almond was also analyzed and a conceptual extractive production model was proposed as a result, in comparison with the extractive models proposed for the Amazon jungle.

\section{MATERIAL AND METHOD}

The primary data were obtained from questionnaires applied to family farmers that are part of the baru productive chain. The Farmers were visited on their property and questions and alternative answers were read and explained. Answers were noted down by the interviewer. The questionnaire also presented open questions, whose answers were noted down as well. Nineteen family farmers were selected by the non-probabilistic method, since it depended on the researcher's judgment. In this case, all the farmers who collected, extracted and marketed the almond of baru and who lived in the municipalities of Formosa and Pirenopolis, in the state of Goias, were sampled. The other criterion was that these farmers should reside in the mentioned municipalities, where the species Dipteryx alata Vogel is naturally present.

\subsection{MEASUREMENT OF SUSTAINABILITY}

Indicators were developed to determine environmental, social, economic, political and health sustainability, with the purpose of measuring the sustainability of the baru almond exploration activity by family farmers.

The indicators adopted to measure the ecological dimension were intended to assess whether baru exploitation has been carried out in a way that causes the least possible impact on native Cerrado vegetation. In the social dimension, we sought to ascertain whether these farmer-gatherers were organized for production and market access. In the economic dimension the intention was to verify the efficiency of the communities in the management of the exploited resource - the baru. Political dimension indicators have served to show whether farmer-gatherers are having access to the information and rights that the Democratic State gives them, and finally, health dimension indicators have been employed to uncover elements that could reveal health measures taken by the government in order to serve these actors, providing a better quality of life. The criteria and indicators (C\&I) used were adapted mainly from the work of Ritchie et al. (2001) and de Silva (2007).

The questionnaires containing the selected indicators were applied to the family farmers who explore the baru almond. The results obtained were the basis for the calculation of the Individual Sustainability Index (Iw), Sustainability Index (IS) for the sample and for the calculation of the Sustainability Degree, for comparison purposes. 
Individual Sustainability Index (Iw) - This index was calculated for the five dimensions using the following formula (RABELO and LIMA, 2007; BARRETO et al., 2005; KHAN and PASSOS, 2001; FERNANDES et al., 1997):

$$
I w=\frac{1}{n} \sum\left(\frac{\sum_{i=1}^{m} E i j}{\sum_{i=1}^{m} E \max i}\right)
$$

Equation 1

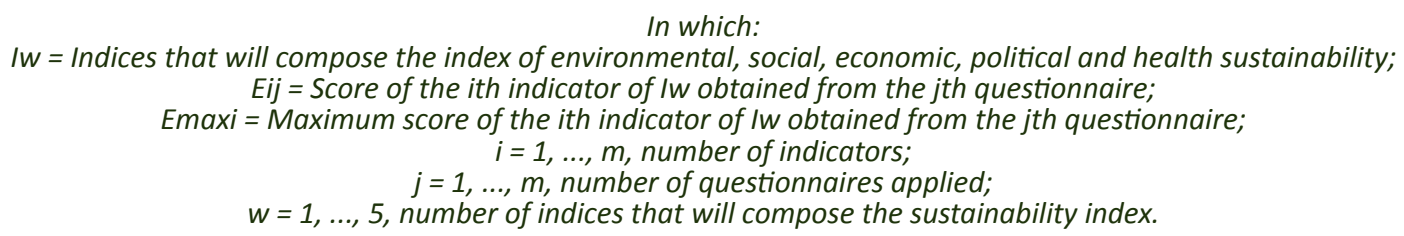

According to the Equation 1, the closer to 1 the value of the Iw index, the better the performance of the study object, that is, the greater the sustainability of the activities developed by the farmers sampled. The indicator is within the range: $0<\mathrm{lw} \leq 1$.

For this methodology, the value of the index will never reach zero because the exploitation of baru is considered an activity of low environmental impact, which automatically allows the family farmers engaged in it to accumulate points.

The questionnaires had questions whose predetermined answers received a score based on a scale of 0 to 4 . In order to calculate the Individual Sustainability Index (Iw), the score obtained by each respondent was added per questionnaire, divided by the maximum number of points that could be obtained.

Sustainability Index (IS) - The environmental, social, economic, political and health indicators were used to calculate the Sustainability Index (IS). Equal weight was assigned to each analyzed dimension. The closer to 1 , the greater the degree of sustainability. The indicator is within the range: $0<1 S \leq 1$.

For the IS calculation, the expression used was as follows (RABELO and LIMA, 2007; BARRETO et al., 2005; KHAN and PASSOS, 2001; FERNANDES et al., 1997):

$$
I S=\frac{1}{k} \sum_{w=1}^{k} I w
$$

Equation 2

$$
\begin{gathered}
\text { In which: } \\
\text { IS = sustainability index; } \\
w=\text { value of the } \text { wth indicator; } w=1, \ldots k .
\end{gathered}
$$

Degree of sustainability - The degree of sustainability of the baru exploration activity was obtained using the Sustainability Indices (IS) numbers. It comprises a scale ranging from 0 to 1 , divided into three distinct levels: low, medium and high level of sustainability. Below 0.500 and above 0 , the activity is characterized by not being sustainable and the public authorities should, together with society, take the necessary measures to solve the problems that caused the index to reach that level and try to make 
the activity as sustainable as possible. When the result of the index goes between 0.500 and 0.799 , it means that the activity studied is reasonably sustainable, but subject to several measures to arrive as close to 1 .

The scale was adapted from the Human Development Index of the United Nations Development Program (UNDP, 1998) and has the following levels: low level of sustainability $(0<1 S \leq 0.499)$; medium level of sustainability $(0.500 \leq \mathrm{IS} \leq 0.799)$; and high level of sustainability $(0,800 \leq \mathrm{IS} \leq 1,000)$.

\subsection{IDENTIFICATION OF OBSTACLES FACED BY FAMILY FARMERS IN THE BARU PRODUCTIVE CHAIN}

In order to identify the obstacles within the baru production chain, 35 forms were presented and read to each interviewed family farmer. They were asked if the obstacles noted in the form matched the ones they encountered in their baru exploration activity. The obtained answers were treated statistically by means of the proportion-comparison test to determine which were statistically significant at the $95 \%$ level.

\subsection{PROPOSITION OF THE PRODUCTIVE MODEL OF BARU}

The model of baru almond production in the Goias savannah is based on the data collected from the applied questionnaires, direct observation, semi structured interviews and document analysis. The primary data were obtained directly from family farmers and private organizations that process the almond. The model of baru exploration proposed allowed the comparison between the studies realized by Rego (1992), Homma (1993) and Drummond (1996).

\section{RESULTS AND DISCUSSION}

\subsection{SUSTAINABILITY INDEX}

The Sustainability Index with the highest number among the interviewed farmers was obtained from a family that tries to use environmentally correct procedures in their property (Family 11, Table 1). The family uses agroecological techniques to grow grains, fruits and vegetables on their property, in addition maintain permanent protection areas - APP and legal reserve - RL in their lands. They hoe around baru seedlings that germinate naturally to avoid competition from other species. The workforce is familial. Parents are helped in their daily tasks by two adult children, in production organization and property administration. A small agro-industry is installed in the property where the baru almond is toasted and wrapped, and where jams and canned fruit from the savannah are made.

This small factory is managed by the Community Development Association of Caxambu formed by the family and other farmers who live in the neighborhood. Economically, this family supports itself with the production of goods (milk, poultry, eggs, vegetables, grains), they get their share in the Association's sales and rural retirement pension. They are socially active people who participate in and maintain good relationships with the rural community. They receive visits and guidance from researchers and technicians from public and private institutions. The family also continually participates in meetings, fairs and training aimed at family agriculture.

On the other hand, the Sustainability Index with the lowest result came from a family from the district of Bom Jesus, in Pirenopolis (Family 13, Table 1). Pastures and improvements (buildings, corral, grass and farmyard) occupy $83 \%$ of the property. The rest is taken by APP and RL (17\%). The owners do not perform any farming practices with the baru seedlings that grow naturally. They do not develop agricultural activities and do not employ sustainable management practices to livestock they raise. They claim to never have received any public or private technical assistance. 
Although they remain associated, they left the Association of Residents of Bom Jesus for incompatibility with other associates. They participate in very few social activities in the community. Only the owner and her son develop activities with baru. They collect the fruits, process and market the almond. The income obtained from the exploitation of the almond is in the range of $1 \%$ to $20 \%$ of what the family makes throughout the year. They consider baru to be a supplement to family income. Most of their annual income comes from rural retirement and a small carpentry work that the family exploits on the property.

According to Table 1, Politics was the dimension that attained the lowest sustainability index among the 19 interviewed farmers. This score could be attributed to the absence of the State in stimulating participatory processes capable of ensuring the exercise of citizenship in visited communities, as well as to the inefficient public services and the basic infrastructure deficit affecting farmers and their families.

Table 1 | Individual Sustainability Index (Iw) by dimension of sustainability, by farmer, by sampled locality.

\begin{tabular}{|c|c|c|c|c|c|c|c|}
\hline $\begin{array}{c}\text { Number of the ques- } \\
\text { tionnaires }\end{array}$ & District & Social Index & $\begin{array}{l}\text { Political } \\
\text { index }\end{array}$ & $\begin{array}{l}\text { Health } \\
\text { index }\end{array}$ & $\begin{array}{l}\text { Economic } \\
\text { index }\end{array}$ & $\begin{array}{l}\text { Ecological } \\
\text { index }\end{array}$ & $\begin{array}{c}\text { General } \\
\text { index by } \\
\text { farmer }\end{array}$ \\
\hline 1 & Caxambu & 0,760 & 0,500 & 1,000 & 0,478 & 0,524 & 0,652 \\
\hline 2 & Caxambu & 0,920 & 0,500 & 1,000 & 0,478 & 0,524 & 0,684 \\
\hline 3 & $\begin{array}{c}\text { Vale da } \\
\text { Esperança }\end{array}$ & 0,880 & 0,111 & 1,000 & 0,217 & 0,667 & 0,575 \\
\hline 4 & $\begin{array}{l}\text { Vale da } \\
\text { Esperança }\end{array}$ & 0,920 & 0,167 & 1,000 & 0,870 & 0,571 & 0,706 \\
\hline 5 & $\begin{array}{c}\text { Vale da } \\
\text { Esperança }\end{array}$ & 0,720 & 0,111 & 1,000 & 0,261 & 0,524 & 0,523 \\
\hline 6 & $\begin{array}{c}\text { Vale da } \\
\text { Esperança }\end{array}$ & 0,840 & 0,556 & 1,000 & 0,435 & 0,524 & 0,671 \\
\hline 7 & $\begin{array}{l}\text { Vale da } \\
\text { Esperança }\end{array}$ & 0,840 & 0,667 & 1,000 & 0,435 & 0,619 & 0,712 \\
\hline 8 & $\begin{array}{l}\text { Vale da } \\
\text { Esperança }\end{array}$ & 0,560 & 0 & 1,000 & 0,348 & 0,619 & 0,505 \\
\hline 9 & $\begin{array}{l}\text { Vale da } \\
\text { Esperança }\end{array}$ & 0,840 & 0,333 & 1,000 & 0,696 & 0,571 & 0,688 \\
\hline 10 & Caxambu & 0,600 & 0,389 & 0,889 & 0,478 & 0,667 & 0,605 \\
\hline 11 & Caxambu & 1,000 & 0,556 & 1,000 & 0,696 & 0,619 & 0,774 \\
\hline 12 & Bom Jesus & 0,72 & 0,167 & 0,889 & 0,435 & 0,714 & 0,585 \\
\hline 13 & Bom Jesus & 0,640 & 0 & 0,889 & 0,391 & 0,524 & 0,489 \\
\hline 14 & Bom Jesus & 0,680 & 0,167 & 0,889 & 0,478 & 0,667 & 0,576 \\
\hline 15 & Bom Jesus & 0,800 & 0 & 0,889 & 0,435 & 0,667 & 0,558 \\
\hline 16 & $\begin{array}{c}\text { Vale da } \\
\text { Esperança }\end{array}$ & 0,960 & 0 & 1,000 & 0,174 & 0,619 & 0,551 \\
\hline 17 & Bom Jesus & 0,640 & 0,278 & 1,000 & 0,478 & 0,667 & 0,613 \\
\hline 18 & Caxambu & 0,760 & 0,389 & 1,000 & 0,565 & 0,476 & 0,638 \\
\hline 19 & Bom Jesus & 0,920 & 0 & 1,000 & 0,565 & 0,714 & 0,640 \\
\hline $\begin{array}{l}\text { Sustainability Index } \\
\text { by dimension }\end{array}$ & & 0,789 & 0,257 & 0,970 & 0,469 & 0,604 & 0,618 \\
\hline
\end{tabular}

Source: Research data/Author (2011).

Although there is not much information linking the exploitation of natural resources with the health and welfare of a population, strong evidence demonstrates a relationship of dependence between these two factors. Several authors have pointed to the existence of interrelationships between environmental degradation and population health problems (KING, 1990; JAMETON; PIERCE, 2002; NUNES; MATIAS, 2006; SANDIFER, et al, 2015). 
In the theoretical framework of sustainable development, the balance between its dimensions is a fundamental factor to reach a correct development model (SACHS, 2000). Because the sustainability of an agro-extractive system is understood as the capacity of this system to remain economically productive, environmentally balanced and capable of providing social justice (CAPORAL; COSTABEBER, 2002), health and well-being over time, the health dimension is an important component in achieving a balance between these dimensions. The health dimension is achieved (IS = 1) by incorporating health into sustainable development strategies and policies and recognizing them as a fundamental human right.

In the studied case, the overall health dimension index reached 0.9687 for the three studied communities, which is considered a high level of sustainability. This result comes from the fact that the interviewed farmer-collectors have quality running water and electric light in their homes, which also have an internal toilet and a septic tank. They are not visited by health agents, but are satisfied with the care offered at health centers of the municipality or public network hospitals in Brasilia, where the farmers go to in cases of more serious diseases.

\subsection{THE PRODUCTIVE MODEL OF BARU}

The production system is characterized by the intensive use of land through the diversification of agricultural activities (diversified agriculture, dairy farming, small animal husbandry) and adoption of non-agricultural activities, such as sales of services, agro-extractivism and trade.

This system production units are owned or received by means of concession of use (settlements of the agrarian reform). Its dimensions range from 15 ha to 115 ha, with the majority being 15 ha, 22 ha and 25 ha.

They use predominantly family labor (84.2\%) and have as main sources of income livestock, agriculture, services and the exploitation of non-timber forest products (NTFP) (Table 2).

Animal production is the predominant activity in 18 properties. Livestock farming is practiced by 16 farmers and 12 of them also plant on their land. The ones mostly used for the market are milk cows and one year-old calves. Bird breeding is practiced in 18 agricultural units, two of which do it for commercial purposes, while the rest for subsistence.

Agricultural products grown on farms are basically for family consumption, with small surpluses reserved for commercialization. The planted areas vary from 1 to 3 ha and are intercropped with pumpkin, watermelon, manioc, sesame, among other crops.

Table 2 | Three main income source of farmers by ascending order of importance.

\begin{tabular}{|c|c|c|c|}
\hline Income source & Frequency & Percentage & $\begin{array}{c}\text { Accumulated } \\
\text { percentage }\end{array}$ \\
\hline Commerce, agro-industry, NTFP & 1 & 5,3 & 5,3 \\
\hline Rural retirement pension, commerce, NTFP & 1 & 5,3 & 10,5 \\
\hline Agriculture, rural retirement pension, agro-industry & 1 & 5,3 & 15,8 \\
\hline Sales of service, agro-industry, agriculture & 1 & 5,3 & 21,1 \\
\hline Sales of service, agro-industry, NTFP & 1 & 5,3 & 26,3 \\
\hline Livestock, commerce, agro-industry & 1 & 5,3 & 31,6 \\
\hline Livestock, rural retirement pension, sales of service & 1 & 5,3 & 36,8 \\
\hline Livestock, agriculture, agro-industry & 1 & 5,3 & 42,1 \\
\hline Livestock, rural retirement pension, agro-industry & 1 & 5,3 & 47,4 \\
\hline Livestock, agro-industry, NTFP & 2 & 10,5 & 57,9 \\
\hline Livestock, sales of service, NTFP & 4 & 21,1 & 78,9 \\
\hline Livestock, agriculture, NTFP & 4 & 21,1 & 100,0 \\
\hline Total & 19 & 100,0 & \\
\hline
\end{tabular}

Source: Research data/Author (2011). 
The data collected in the field provided the elements that made it possible to identify the productive chain of baru, structured according to Figure 1.

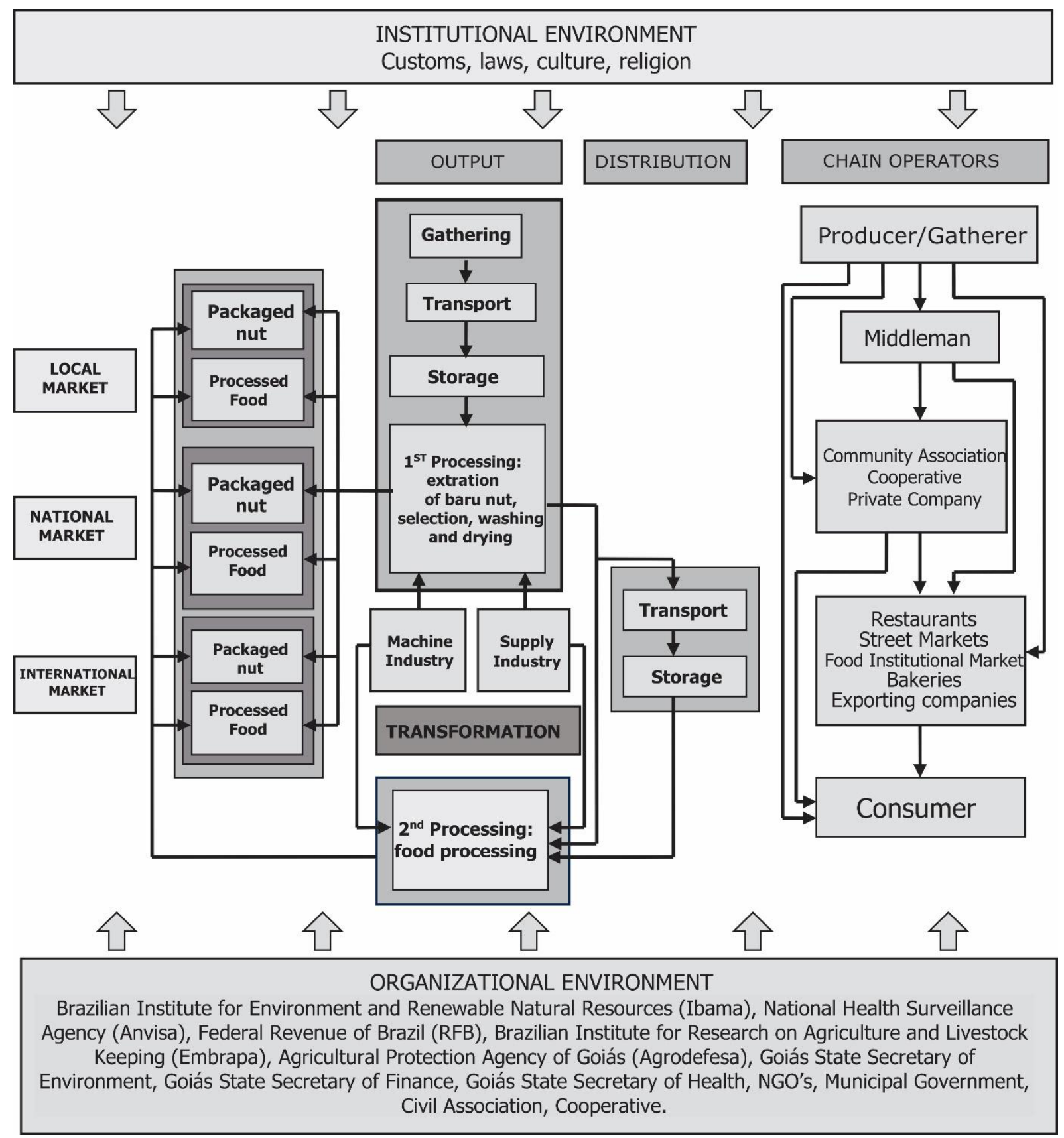

Figure 1 | Generic model of the productive chain of baru in the State of Goias and Distrito Federal, 2011.

Source: Research data/Author (2011). 
The definition of the baru productive chain was an important step in proposing a productive model for this almond. Figure 2, below, illustrates the generic model found in the areas studied having the family farmer, private organizations and the consumer as main actors.

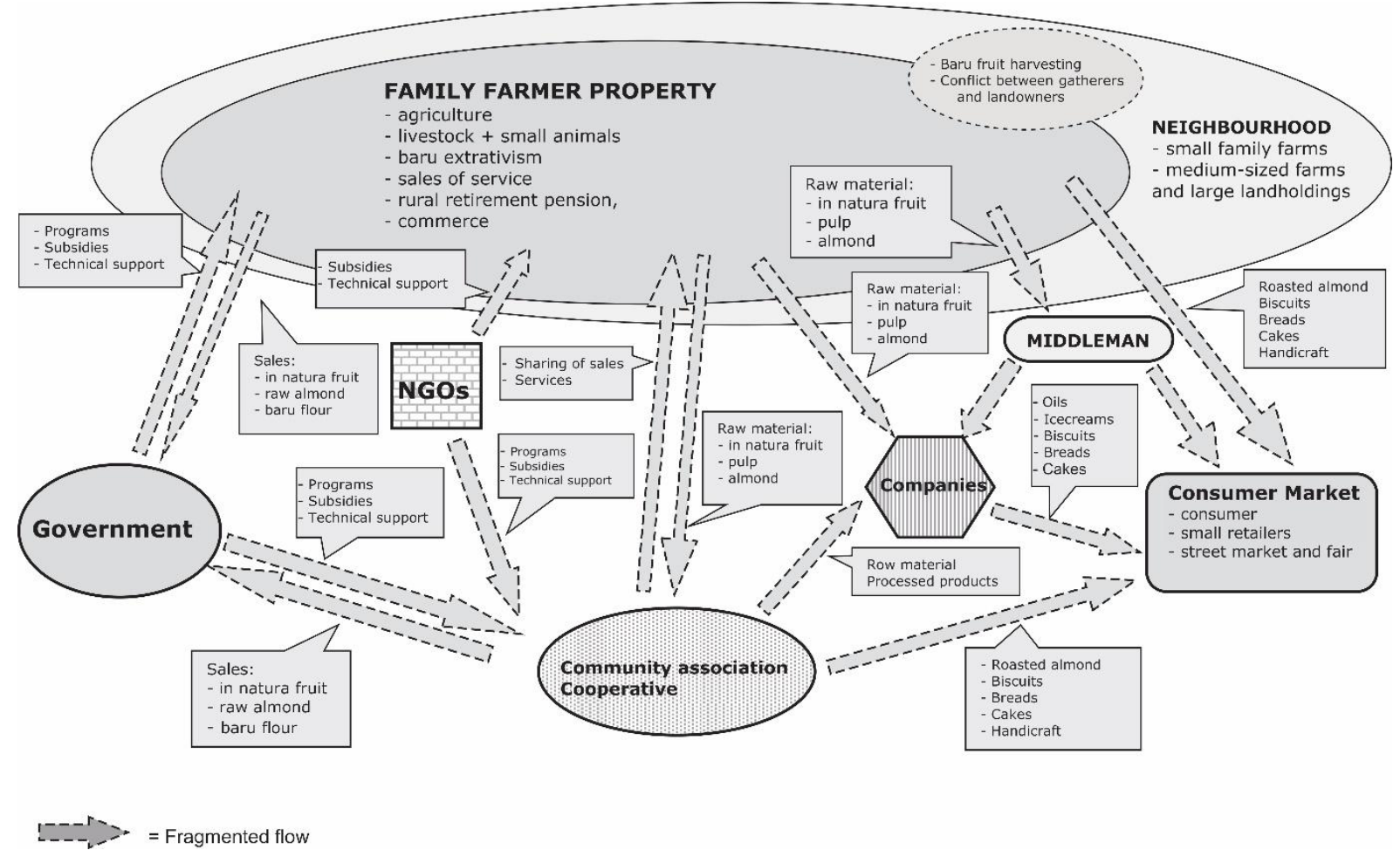

Figure 2 | Conceptual model of exploitation of baru found in municipalities in the state of Goias and Distrito Federal, 2011.

Source: Research data/Author (2011).

According to the conceptual model proposed here, the commercial relationship between the baru almond collector (family farmer) and buyers (associations/cooperatives, companies, brokers, consumers, the Federal Government) is fragmented due to the irregularity of the product supply, which may be due to factors such as the seasonality of fruiting, irregularity in the quantities produced by the trees and the lack of an appropriate place to store the product. Decapitalization and credit restrictions are factors that make it difficult to store the fruit in sufficient quantity for the off-season period.

The factors mentioned above have a direct impact on extractivist farmers' associations/cooperatives as for their organization process. In addition, other factors that contribute to the failure of enterprises of this kind are low participation of farmers in the enterprise and their vulnerability to the market, mainly due to their business management inabilities and difficulties they face when complying with administrative procedures required by legislation.

The exploitation of baru in the studied rural communities presents some socioeconomic characteristics that make it different from those activities involved in the exploration of non-timber forest products (NTFPs) in the Amazon, such as: (a) Until recently, in the Amazon, there were prevailing unequal economic and labor relations between "Seringueiros" - rubber tappers and "Seringalistas" - rubber business owners, in which the latter was predominant. Although this characteristic is in clear disappearance, there still persists the figure of the "Regatao/Marreteiro" (exploitative river trader) that submits the extractivist to economic dependence. 
In the Central Region of Brazil, the baru exploitation takes place under other economic and social bases where there usually aren't any identified relations of dependence between the baru collector (family farmer) and the buyer of the fruit; (b) Unlike the Amazonian extractivists who collect NTFPs as their predominant activity and livestock and agriculture as secondary activities, the rural populations that exploit baru have livestock, traditional agriculture, agribusiness, as well as sale services as their main activities; (c) The proximity of the market and greater ease of transportation are an incentive for the commercialization of baru production to be carried out by the families themselves, and there is no dependency or subordination with the buyer of the product; (d) The collectors of baru do not depend on external capital for the collection activity, making use of their own work force for this operation.

\subsection{OBSTACLES TO BARU EXPLORATION}

The obstacles that were statistically significant received more than 13 indications, and they are the ones that correspond to the order of numbers 1 to 4 of Table 3 . The obstacles are: difficulty that farmers possess in the management of collective ventures (association/ cooperative); lack of machinery to remove, break, toast and peel the baru nuts; lack of farmers' ability to produce the baru kernel in satisfactory amounts that can make for constant supply; and lack of dissemination of the nut to consumers.

Table 3 | Number of indications received by obstacle submitted to farmers in the three rural communities studied.

\begin{tabular}{|c|c|c|}
\hline Order number & Obstacles to baru exploration & Number of indications \\
\hline 1 & $\begin{array}{c}\text { Difficulty that farmers possess in the management of } \\
\text { collective ventures (association/ cooperative) }\end{array}$ & 15 \\
\hline 2 & $\begin{array}{c}\text { Lack of machinery to remove, break, toast and peel the } \\
\text { baru nuts }\end{array}$ & 15 \\
\hline 3 & $\begin{array}{c}\text { Lack of farmers' ability to produce the baru kernel in } \\
\text { satisfactory amounts that can make for constant supply }\end{array}$ & 13 \\
\hline 4 & Lack of dissemination of the nut to consumers \\
\hline
\end{tabular}

Source: Research data/Author (2011).

Authors like Sawyer (2009), Enriquez (2008), Gonçalo (2006) and May (2001) cite the following factors as limiting in collection, processing and marketing of NTFPs of native Savanna (Cerrado) species: a) Seasonality and annual variation of production due to the physiological characteristics of the species and the climate; (b) Scale of production insufficient to supply the market in demanded quantity; (c) Difficulty in accessing credit, faced by individuals or enterprises that exploit NTFPs (d) Lack of standard on product size, color, type of packaging, weight, label and composition; (e) Lack of dissemination of Cerrado products to the consumer; (f) Lack of technical assistance to provide support in the production process and in the marketing of products; (g) Difficulties for both family farmers and companies to meet legal requirements (environmental, sanitary, fiscal/ tax); (h) Difficulties in distributing products; (i) Lack of entrepreneurial capacity by the communities to manage the enterprise; (j) Difficulty in managing collective ventures.

Family farmers' difficulty in the management of collective enterprises is an obstacle that has been pointed out by other authors on the topic (ISPN, 2014; SAWYER, REE, PIRES, 1999). The lack of suitable machinery to remove pulp, to break, toast and peel the almonds of the baru is a limiting factor to production. Nowadays, the baru is broken with the help of manual machines that produce a maximum of $3 \mathrm{~kg}$ of almond per day, turning it into a labor-intensive activity that hinders production.

The inability of the farmer to produce the baru nut in sufficient quantity to make the supply constant leads to an irregular supply of the market, either because of lack of strategic stocks (lack of working capital, lack of management) or due to seasonality of the fruiting of the species or irregularity in the crops. 
The lack of dissemination of the baru to the consumer is related to the poor public knowledge about the nutritional qualities of the baru almond. Because it is a product whose market can still be considered marginal, it does not have the necessary relevance to be included in massive publicity campaigns such as cashew nut and brazil nut.

\section{CONCLUSIONS}

The results obtained demonstrate that, although baru almond exploration is an economic activity that has benefited a considerable number of family farmers established in properties located in municipalities of the state of Goias, it cannot be characterized as a sustainable income generation alternative, since it only partially meets the requisite that, in order to be considered sustainable, the activity must find a balance among the various dimensions of sustainability.

Among the interviewed farmers, the Sustainability Index that reached the highest value was the economic one (Is = 0.565), showing a greater concern in the economic viability of the activity and ignoring the other dimensions of sustainability. Thus, the results suggest that the first concern of the baru farmers is to get a good price for the almond of baru so that they can meet their immediate needs, relegating the adoption of measures that make their activity be socially fair and environmentally balanced to second place.

The low results on political sustainability (Is $=0.257$ ) can be considered an indicator of the State's deficiency in stimulating participatory processes that could ensure the exercise of citizenship, in actions that seek to overcome deficiencies in public services rendered and in the provision of infrastructure to enable organizations to perform well.

The obstacles faced by farmers can constitute a powerful impediment to the proper management of the exploitation activity of the baru nut, also contributing to the commitment of its sustainability.

The study of the baru productive chain showed that the exploitation of the baru almond can be identified as extractivism with intensive use of unskilled labor and rudimentary technology, being subject to the laws of the market like any other extractive product. It also allowed us to identify a production model with different characteristics from those proposed to explain extractivism. The exploration activity of the baru fruit in the savannah of Goias, shaped by local economic, social, ecological and cultural factors, differs from the models proposed by Rego (1992), Homma (1993) and Drummond (1996) to explain Amazonian extractivism.

\section{ACKNOWLEDGMENTS}

To the Institute for Society, Population and Nature - ISPN, which provided financial resources for the project "FLORELOS: Ecosocial links between Brazilian forests - sustainable livelihoods in productive landscapes", developed with the financial support of the European Union, to carry out this study.

\section{REFERENCES}

BARRETO, R.C.S.; KHAN, A.S.; LIMA, P.V.P.S. Sustentabilidade dos assentamentos no município de Caucaia-CE. Revista de Economia e Sociologia Rural [online], Brasília, v. 43, n. 2, p. 225-247, abr/jun 2005.

CAPORAL, F.R.; COSTABEBER, J.A. Análise multidimensional da sustentabilidade: uma proposta metodológica a partir da agroecologia. Agroecologia e Desenvolvimento Rural Sustentável. Porto Alegre, v. 3, n. 3, p. 70-85, jul./ set. 2002.

DRUMMOND J.A. A extração sustentável de produtos florestais na Amazônia Brasileira. Estudos Sociedade e Agricultura, Rio de Janeiro, v. 6, p.116-137, 1996. 
ENRIQUEZ G.E.V. Desafios da sustentabilidade da Amazônia: biodiversidade, cadeias produtivas e comunidades extrativistas integradas. Tese (Doutorado em Desenvolvimento Sustentável). Centro de Desenvolvimento Sustentável, Universidade de Brasília, Brasília, 2008. 460 f. Available Online at: http://repositorio.unb.br/ bitstream/10482/6730/1/2008_GonzaloEnriqueVasquezEnriquez.pdf. Last accessed: 09 April 2019.

FERNANDES, A.V.; SILVA, L.M.R.; KHAN, A.S. Reserva extrativista do Rio Cajari: sustentabilidade e qualidade de vida. Revista de Economia e Sociologia Rural, Brasília, v.35, n.3, p.119-140, jul/set 1997.

GONÇALO, J.E. Gestão e comercialização de produtos florestais não madeireiros (PFNM) da biodiversidade no Brasil. In: ENCONTRO NACIONAL DE ENGENHARIA DE PRODUÇÃO, 2006, Fortaleza. Anais... Available Online at: http://www.bibliotecaflorestal.ufv.br/handle/123456789/13189. Last accessed: 03 April 2019.

HOMMA, A.K.O. Extrativismo vegetal na Amazônia: limites e oportunidades. Brasília: Embrapa-SPI, 1993.

INSTITUTO SOCIEDADE, POPULAÇÃO E NATUREZA - ISPN. Produtos sustentáveis da Biodiversidade Brasileira: gestão, mercados e políticas públicas. Brasília, 2014. Available Online at: http://www.ispn.org.br/arquivos/TES13-02-Produtos-sustent\%C3\%A1veis.pdf. Last accessed: 02 April 2019.

JAMETON, A.; PIERCE, J. Sustainable health care and emerging ethical responsibilities. In: MCCALLY, M. (Ed.). Life support: the environment and human health. Cambridge: MIT Press, 2002.

KHAN, A.S.; PASSOS, A.T.B. Reforma agrária solidária e qualidade de vida dos beneficiários no estado do Ceará. Revista de Economia e Sociologia Rural, Brasília, v.39, n.4, p. 93-117, out/dez 2001.

KING, M. Health is a sustainable state. The Lancet, London, n. 336, p. 664-667, 1990. DOI:10.1016/01406736(90)92156-c.

MAY, P.H. (Org.) Compilacion y analisis sobre los productos forestales no madereros en el Brasil: relatorio tecnico. Santiago: FAO, 2001. Available Online at: http://www.fao.org/tempref/Gl/Reserved/FTP_FaoRlc/old/ proyecto/rla133ec/PFNM-pdf/PFNM\%20-\%20Brasil.PDF. Last accessed: 09 April 2019.

NUNES, J.A.; MATIAS, M. Rumo a uma saúde sustentável: saúde, ambiente e política. Saúde e Direitos Humanos, ano 3, n. 3, p. 7-16, 2006.

RABELO, L.S.; LIMA, P.V.P.S. Indicadores de sustentabilidade: a possibilidade de mensuração do desenvolvimento sustentável. Revista Eletrônica do Prodema, Fortaleza, v.1, n.1, p. 55-76, dez/2007.

RÊGO, J.F. do. Amazônia: do extrativismo ao neoextrativismo. Ciência Hoje, Rio de Janeiro, v.25, n.147, p. 62-65, 1992.

RITCHIE, B.; MCDOUGALL, C.; HAGGITH, M.; OLIVEIRA, N.B. Sustainability criteria and indicators in communitymanaged forests: An introductory guide. Jakarta: CIFOR, 2001. 124 p.

SACHS, I. Caminhos para o desenvolvimento sustentável. Rio de Janeiro: Garamond, 2000.

SANDIFER, P.; SUTTON-GRIER, A.E.; WARD, B. Exploring connections among nature, biodiversity, ecosystem services, and human health and well-being: Opportunities to enhance health and biodiversity conservation. Ecosyst Serv, v. 2, p. 1-15, 2015. DOI:10.1016/j.ecoser.2014.12.007.

SANO, S.M.; RIBEIRO, J.F.; BRITO, M.A. de. Baru: biologia e uso. Planaltina: Embrapa Cerrados, 2004.

SAWYER, D.R. Entraves regulatórios de atividades extrativistas na Amazônia: problemas, enfrentamento e soluções. In: Soerguimento tecnológico e econômico do extrativismo na Amazônia. Brasília, DF: Centro de Gestão de Estudos Estratégicos, 2011. p. 197-251.

SAWYER, D.R.; VAN DER REE, M.; PIRES, M. O. Comercialização de espécies nativas do Cerrado. In: ENCONTRO REGIONAL CENTRO-OESTE, 6., 1997, Brasília. Os (des)caminhos do desenvolvimento rural brasileiro, Anais... Brasília: Associação Projeto de Intercâmbio de Pesquisadores Sociais da Agricultura, 1997. p. 149-169. 
SERVIÇO BRASILEIRO DE APOIO ÀS MICRO E PEQUENAS EMPRESAS - SEBRAE. Fatores condicionantes e taxas de sobrevivência e mortalidade das micro e pequenas empresas no Brasil: 2003-2005. Brasília, Agos. 2007. 56p. Available Online at: http://www.bibliotecas.sebrae.com.br/chronus/ARQUIVOS_CHRONUS/bds/bds. nsf/8F5BDE79736CB99483257447006CBAD3/\$File/NT00037936.pdf. Last accessed: 09 April 2019.

SILVA, J.M. da; SANTOS, J.R. dos. Pegada ecológica: instrumento de avaliação dos impactos antrópicos no meio natural. Oecologia Brasiliensis, Rio de Janeiro, v. 11, n. 4, p. 574-581, 2007.

TOGASHI, M.; SGARBIERI, V.C. Avaliação nutricional da proteína e do óleo de sementes de baru (Dipteryx alata Vog). Ciência e Tecnologia de Alimentos, Campinas, v.15, n.1, p. 66-69, 1995.

UNITED NATIONS/UNITED NATIONS DEVELOPMENT PROGRAMME - UNDP. Humam development report 1998. New York: UNDP, 1998. Available Online at: http://hdr.undp.org/en/media/hdr_1998_en_definitions.pdf. Last accessed: 08 November 2010. 